\title{
Application of Stir Bar Sorptive Extraction to Analysis of Volatile and Semivolatile Organic Chemicals of Potential Concern in Solids and Aqueous Samples from the Hanford Site
}

\section{J. M. Frye and J. M. Kunkel}

Washington River Protection Solutions LLC

Richland, WA 99352

U.S. Department of Energy Contract DE-AC27-08RV14800

\author{
EDT/ECN: DRF UC: \\ Cost Center: 2EK00 Charge Code: \\ B\&R Code: $\quad$ Total Pages: / 7
}

Key Words: SVOA, VOA, COPC, GC/MS, LCS, MDL, PDMS, SBSE, TDU, Twister, analysis, chemicals of potential concern, GERSTEL, Terminal Liquor Standard, stir bar, sorptive extraction, semivolatile organic analysis, volatile organic analysis, thermal desorption tubes, method detection limit, laboratory control standard, gas chromatography, mass spectrometry

Abstract: Stir bar sorptive extraction was applied to aqueous and solid samples for the extraction and analysis of organic compounds from the Hanford chemicals of potential concern list, as identified in the vapor data quality objectives. The 222-S Laboratory analyzed these compounds from vapor samples on thermal desorption tubes as part of the Hanford Site industrial hygiene vapor sampling effort.

TRADEMARK DISCLAIMER. Reference herein to any specific commercial product, process, or service by trade name, trademark, manufacturer, or otherwise, does not necessarily constitute or imply its endorsement, recommendation, or favoring by the United States Government or any agency thereof or its contractors or subcontractors.
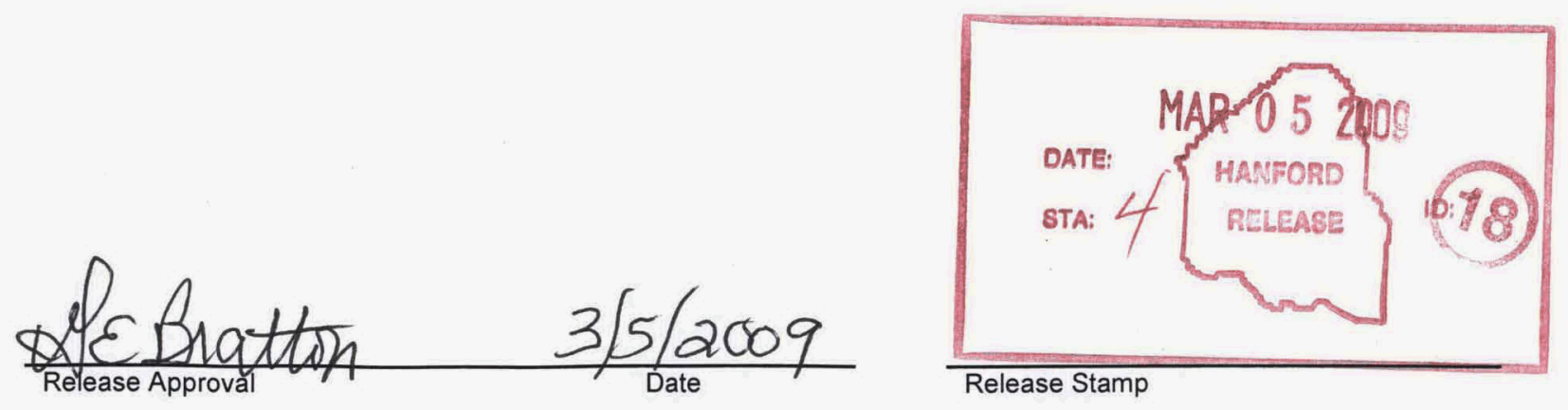

\section{Approved For Public Release}




\section{Application of Stir Bar Sorptive Extraction to Analysis of Volatile and Semivolatile Organic Chemicals of Potential Concern in Solids and Aqueous Samples from the Hanford Site}

J. M. Frye

J. M. Kunkel

Washington River Protection Solutions LLC

January 2009 


\section{TABLE OF CONTENTS}

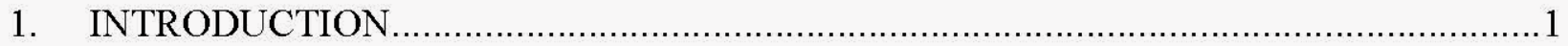

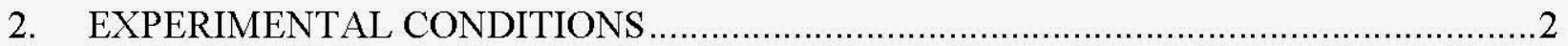

$2.1 \quad$ Semivolatile Organic Analysis Extraction and Analysis .......................................2

2.1.1 Semivolatile Organic Analysis from Liquids Extraction ..................................2

2.1.2 Semivolatile Organic Analysis from Solids Extraction .................................... 4

$2.2 \quad$ Volatile Organic Analysis Extraction and Analysis .............................................

2.2.1 Volatile Organic Analysis from Liquids Extraction Conditions ...........................5

2.2.2 Volatile Organic Analysis from Solids Extraction Conditions ............................ 5

2.2.3 Volatile Organic Analysis Conditions ................................................................ 5

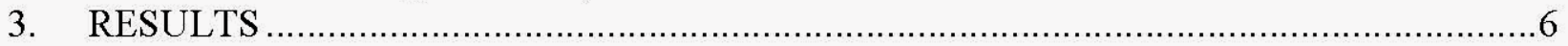

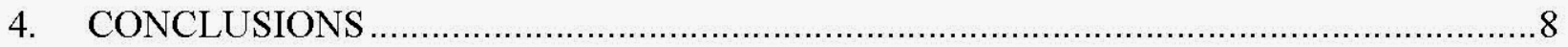

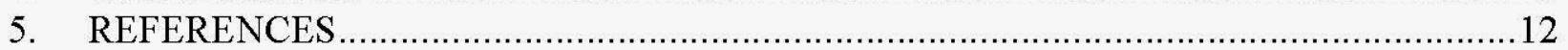

\section{List of Figures}

Figure 1. Volatile Organic Analysis Chromatogram Example 9

Figure 2. Semivolatile Organic Analysis Chromatogram Example........................................10

\section{List of Tables}

Table 1. Method Detection Limit Comparison between Twister and Thermal Desorption Tubes Methods

Table 2. Chemicals of Potential Concern Compound $\mathrm{K}_{\mathrm{ow}}$ Values........................................... 7

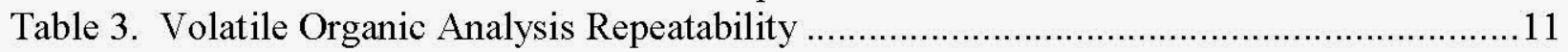

Table 4. Semivolatile Organic Analysis Repeatability ................................................ 11

Table 5. Percent Recovery of LCS Standards in Terliq with Twister...................................11

\section{ABBREVIATIONS AND ACRONYMS}

COPC chemicals of potential concern

GC/MS gas chromatography/mass spectrometry

LCS laboratory control standard

MDL method detection limit

PDMS polydimethylsiloxane

SBSE stir bar sorptive extraction

SVOA semivolatile organic analysis

TDU thermal desorption tubes

Terliq Terminal Liquor Standard

Twister GERSTEL ${ }^{\circledR}$ Twister

VOA volatile organic analysis 


\section{INTRODUCTION}

Stir bar sorptive extraction (SBSE) was applied to aqueous and solid samples for the extraction and analysis of organic compounds from the Hanford Site chemicals of potential concern (COPC) list, as identified in the vapor data quality objectives. The 222-S Laboratory analyzed these compounds from vapor samples on thermal desorption tubes (TDU) as part of the Hanford Site industrial hygiene vapor sampling effort. For this reason, these compounds were chosen for testing SBSE (interoffice memorandum7S110-JMF-07-132, "Development of Stir Bar Sorptive Extraction as Applied to Hanford Tank Waste Liquids and Solids or Soils").

The extractions were performed by either immersing the SBSE in the aqueous sample for a set period of time and a set revolutions per minute, or by suspending it above the surface of the sample in a sealed headspace vial for a set period of time and temperature. Unlike classical extraction techniques in which the compounds of interest are extracted from a complicated matrix using liquid-liquid extraction, in SBSE the compound of interest is extracted into the solid sorbent phase, which is coated onto the surface of a glass stir bar. The SBSEs used for this test were GERSTEL-Twister ${ }^{\circledR}$ (Twister) ${ }^{1}$ bars. Twisters are glass-covered magnetic stir bars that have a thick film $(0.5 \mathrm{~mm})$ of polydimethylsiloxane (PDMS). The PDMS is used to extract nonpolar compounds from polar matrices. It is possible to obtain an indication of how well a particular compound will extract into the Twister using the octanol/water coefficient $\left(\mathrm{K}_{\mathrm{ow}}\right)$. Compounds with extremely low $\mathrm{K}_{\text {ow }}$ are less likely to be absorbed into the PDMS phase. SBSE technique was applied successfully to the less polar volatile organic analysis (VOA) compounds on the COPC list on both solids and liquids, and to semivolatile organic analysis (SVOA) compounds on the list from liquids.

Procedures ATS-LT-523-161, "222-S Laboratory Analysis of Semivolatile Organic Compounds Collected by Twister Stir-bar Sorptive Extraction by Gas Chromatography / Mass Spectrometry," and ATS-LT-523-162, "Analysis of Volatile Organic Compounds Collected on Twister Stir Bar Sorptive Extractors by Gas Chromatography/Mass Spectrometry," were developed as a result of this research. Experimental notes and results are documented in controlled notebook HNF-N-422, 2, Analytical Development Projects, pages 35 to 63 and 66 to 93. The compounds in Table 1 were successfully analyzed using this technique. The SVOA liquid method detection limits (MDL) were determined on two different gas chromatography/mass spectrometry (GC/MS) instruments, identified in the laboratory database as Spock and Sulu. The SVOA results obtained on these two different instruments were comparable. The MDL values determined for the same compounds from TDU tubes using a modified U.S. Environmental Protection Agency method are listed for comparison (Compendium Method TO-17, Determination of Volatile Organic Compounds in Ambient Air Using Active Sampling onto Sorbent Tubes). The TDU VOA MDLs were determined from Carbotrap ${ }^{\mathrm{TM}^{2}} 300$ tubes, and the TDU SVOA MDLs were determined from Carbotrap 150 tubes in 2007 from GC/MS Scotty and GC/MS Sulu. These MDLs are recalculated periodically and change.

\footnotetext{
${ }^{1}$ GERSTEL-Twister ${ }^{\circledR}$ is a registered trademark of Gerstel, Inc., Caton Research Center, Baltimore, Maryland.

${ }^{2}$ Carbotrap $^{\mathrm{TM}}$ is a registered trademark of Supelco, Bellefonte, Pennsylvania.
} 
Table 1. Method Detection Limit Comparison between Twister and Thermal Desorption Tubes Methods

\begin{tabular}{|c|c|c|c|c|}
\hline Compound & $\begin{array}{l}\text { VOA from Solid, } \\
\text { MDL (ng) }\end{array}$ & $\begin{array}{l}\text { VOA from } \\
\text { Liquid, MDL } \\
\text { (ng) }\end{array}$ & $\begin{array}{l}\text { SVOA from } \\
\text { Liquid, MDL } \\
\text { (ng) }\end{array}$ & $\begin{array}{c}\text { MDLs Using } \\
\text { TDU Tubes } \\
\text { (ng) }\end{array}$ \\
\hline Instruments & Sulu & Sulu & -- & Scotty \\
\hline 2-Methylfuran & 10.78 & 20.57 & NA & 5.95 \\
\hline 2,5-Dihydrofuran & 10.75 & 16.00 & NA & 6.68 \\
\hline Butanal & 34.43 & 31.92 & NA & 10.53 \\
\hline Benzene & 6.98 & 9.99 & NA & 6.91 \\
\hline Butanenitrile & 7.08 & 14.59 & NA & 20.32 \\
\hline 3-Butene-2-one & 11.32 & NA & NA & 6.49 \\
\hline 1-Butanol & 15.29 & NA & NA & 7.41 \\
\hline Pyridine & 9.26 & 14.75 & NA & 16.83 \\
\hline 2-Hexanone & 9.66 & 11.74 & NA & 5.26 \\
\hline Pentanenitrile & 14.48 & 12.09 & NA & 5.11 \\
\hline 2,4-Dimethylpyridine & 9.56 & 10.08 & NA & 12.60 \\
\hline Hexanenitrile & 12.64 & 8.05 & NA & 3.82 \\
\hline Instruments & -- & -- & Spock, & Sulu \\
\hline Biphenyl & NA & NA & 3.73 & 1.49 \\
\hline Diethylphthalate & NA & NA & 6.20 & 6.56 \\
\hline Dibutylbutylphosphonate & NA & NA & 4.05 & 1.03 \\
\hline Tributylphosphate & $\mathrm{NA}$ & NA & 4.10 & 1.26 \\
\hline
\end{tabular}

Some VOA compounds like 3-Butene-2-one and 1-Butanol were too polar to be extracted from the aqueous phase with good repeatability into the PDMS phase of the Twister. Note that butanal, which is also a small polar compound, had an elevated MDL when compared to the other compounds. The SVOA compounds could not reliably be extracted from solids. The MDL values obtained for the less polar, longer chain VOA compounds, and the SVOA compounds are in the same range as those determined off of TDU tubes.

\section{EXPERIMENTAL CONDITIONS}

\subsection{SEMIVOLATILE ORGANIC EXTRACTION AND ANALYSIS}

\subsubsection{Semivolatile Organic Analysis from Liquids Extraction}

The SVOA from liquids were extracted by placing $10 \mathrm{~mL}$ of water in a $10-\mathrm{mL}$ glass headspace vial. The water was adjusted to $\mathrm{pH} 10$ with five drops of $0.125 \mathrm{M} \mathrm{NaOH}$.Calibration standards 
were added to the vials along with a Twister stir bar extractor. The vials were capped and stirred at $1000 \mathrm{rpm}$ for 60 minutes. After this extraction time, the Twisters were removed from the vial and placed in an empty glass TDU tube and desorbed on the GERSTEL TDS $3^{3}$ at $280{ }^{\circ} \mathrm{C}$. The analysis was run on an Agilent ${ }^{4}$ 6890GC/Agilent 5973MSD equipped with a GERSTEL TDS 3 , using the conditions listed in the following:

\begin{tabular}{|c|c|}
\hline Initial column temperature: & $40^{\circ} \mathrm{C}$ for 1 minute \\
\hline Column temperature program: & $\begin{array}{l}40-300{ }^{\circ} \mathrm{C} \text { at } 15^{\circ} / \text { minute, } \\
300-315^{\circ} \mathrm{C} \text { at } 6 \% \text { minute, hold } \\
6 \text { minutes }\end{array}$ \\
\hline Final column temperature: & $315^{\circ} \mathrm{C}$ for 6 minutes \\
\hline Column: & $\begin{array}{l}\text { Agilent } 122-5536 \mathrm{DB}-5 \mathrm{~ms} \text {, } \\
30 \mathrm{~m} \times 0.25 \mathrm{~mm} \times 0.5 \mu \mathrm{m} \text {, (or } \\
\text { equivalent) } \max \text { temperature } 325 \\
\text { installed in back inlet. }\end{array}$ \\
\hline Transfer line temperature: & $300^{\circ} \mathrm{C}$ \\
\hline Back inlet, GERSTEL CIS 3: & $\begin{array}{l}\text { Back inlet mode: solvent vent } \\
\text { Initial temp: }-30^{\circ} \mathrm{C} \\
\text { Equilibration time: } 0.20 \text { minutes } \\
\text { Initial time: } 0.20 \text { minutes } \\
\text { Ramp rate: } 12^{\circ} \mathrm{C} / \mathrm{s} \\
\text { Final temperature: } 300^{\circ} \mathrm{C} \\
\text { Hold time: } 3.00 \text { minutes }\end{array}$ \\
\hline Carrier gas: & $\begin{array}{l}\text { Helium at flow recommended by } \\
\text { manufacturer. }\end{array}$ \\
\hline GC run time: & 29.83 minutes \\
\hline
\end{tabular}

${ }^{3}$ GERSTEL Thermal Desorption Unit TDS 3 is a product of Gerstel, Inc., Baltimore, Maryland.

${ }^{4}$ Agilent is a registered trademark of Agilent Technologies, Inc., Santa Clara, California. 
The following conditions were used on the Gerstel TDS3.

TDS 3 parameters:

Sample mode: Sample remove

Flow mode: Splitless

Initial temp: $30^{\circ} \mathrm{C}$

Initial time: 0.00 minutes

Delay time: 0.50 minutes

Purge time: 0.00 minutes

Transfer temp: $300{ }^{\circ} \mathrm{C}$

$1^{\text {st }}$ Rate: $60^{\circ} \mathrm{C} /$ minutes

$1^{\text {st }}$ Final temp: $280^{\circ} \mathrm{C}$

$1^{\text {st }}$ Final time: 8.00 minutes

$2^{\text {nd }}$ Rate: $0{ }^{\circ} \mathrm{C}$

$2^{\text {nd }}$ Final temp: $0{ }^{\circ} \mathrm{C}$

$2^{\text {nd }}$ Final time: 0.00 minutes

Run parameters: $\quad$ Run time: 15.00 minutes

Solutions were adjusted to $\mathrm{pH} 10$ to mimic what might be encountered from Hanford radioactive tank waste samples, which are strongly basic. The $\mathrm{pH} 10$ solutions did increase the number of siloxane type compounds present in the chromatograms. If the samples to be analyzed are not basic, then the calibration and samples could be run without adjusting the $\mathrm{pH}$ to 10 . Tank simulant samples were extracted at $\mathrm{pH}$ values above $\mathrm{pH} 10$, but fewer siloxane peaks were seen and better recovery of target compounds were obtained when the $\mathrm{pH}$ was adjusted back down to $\mathrm{pH} 10$ with dilute nitric acid. For this comparison, an aliquot $(1 \mathrm{~mL})$ of tank simulant was added to $10 \mathrm{~mL}$ water in the Twister vial and spiked with a laboratory control standard (LCS). Another vial was prepared in the same way, but the $\mathrm{pH}$ was adjusted with $0.5 \mathrm{~N}$ nitric acid. The amount of nitric acid needed to bring the solution back down to $\mathrm{pH} 10$ nearly doubled the volume in the vial. Extractions and analysis were performed in the same manner.

\subsubsection{Semivolatile Organic Analysis from Solids Extraction}

Efforts were made to determine if SVOA compounds could be extracted from a solid by suspending the Twister above the solid in a sealed headspace vial. Glass beads, 100 to 120 mesh size, were used to simulate a clean solid. These efforts were unsuccessful as the SVOA compounds had insufficient vapor pressure to be determined from a solid with the necessary accuracy, even when heated up to $200{ }^{\circ} \mathrm{C}$ dry or to $135^{\circ} \mathrm{C}$ with a few drops of water added. 


\subsection{VOLATILE ORGANIC EXTRACTION AND ANALYSIS}

\subsubsection{Volatile Organic Analysis from Liquids Extraction Conditions}

Liquids were extracted by placing $10 \mathrm{~mL}$ of water adjusted to $\mathrm{pH} 10$ using five drops of $0.125 \mathrm{M}$ $\mathrm{NaOH}$ in a $10-\mathrm{mL}$ Twister vial. Approximately $1 \mathrm{~g}$ of sodium sulfate, measured with a scoop, was added to the vials. The vials were spiked with $0.5 \mu \mathrm{L}$ of calibration standards and $0.05 \mu \mathrm{L}$ of internal standard solution. A Twister was added, and the vial was capped immediately. The vials were allowed to stir at room temperature at $1000 \mathrm{rpm}$ for 60 minutes.

\subsubsection{Volatile Organic Analysis from Solids Extraction Conditions}

Approximately $1 \mathrm{~g}$, measured volumetrically with a marked scoop, of 100- to 200-mesh glass beads were placed in a $20-\mathrm{mL}$ headspace vial. The glass beads were spiked with calibration standards, a Twister was suspended above the glass beads, and the vial was sealed. The vials were heated at $65^{\circ} \mathrm{C}$ in a block heater for 2 hours. The Twisters were then removed and placed in an empty glass TDU tube and desorbed at $250^{\circ} \mathrm{C}$. Initially in these studies the Twisters were heated to $75^{\circ} \mathrm{C}$ for the extraction and $280^{\circ} \mathrm{C}$ for the desorption. While this worked and produced usable calibration curves, it caused larger siloxane-type artifact peaks than using the lower temperature.

\subsubsection{Volatile Organic Analysis Conditions}

\subsubsection{Gas Chromatography Conditions}

Initial column temperature:

Column:

Column temperature program:

Final column temperature:

Run time:

Transfer line temperature:

Carrier gas:
$40{ }^{\circ} \mathrm{C}$ for 6 minutes

Restek Rtx-VMS, $60 \mathrm{M} \times 0.25 \mathrm{~mm}$ with a 1.4-micron film thickness.

$40-80^{\circ} \mathrm{C}$ at 6 degrees/minute, hold for 5 minutes, $8^{\circ} \mathrm{C} /$ minute to $95^{\circ} \mathrm{C}$, hold for 11 minutes, $12^{\circ} \mathrm{C} /$ minutes, to $197^{\circ} \mathrm{C}$

$197^{\circ} \mathrm{C}$ for 5 minutes

44.04 minutes

$300{ }^{\circ} \mathrm{C}$

Helium at flow recommended by manufacturer. 
Back inlet: Gerstel CIS3

IDS 3 parameters

Initial temperature:

Delay time:

Rate

End temperature:

Hold time:
Back Inlet Mode: Solvent

vent

Initial temp: $-30{ }^{\circ} \mathrm{C}$

Equilibration time: $0.20 \mathrm{~min}$

Initial time: $0.20 \mathrm{~min}$

Ramp rate: $12^{\circ} \mathrm{C} / \mathrm{s}$

Final Temperature: $300^{\circ} \mathrm{C}$

Hold time: $3.00 \mathrm{~min}$

$30{ }^{\circ} \mathrm{C}$

0.50 minutes

$60{ }^{\circ} \mathrm{C} /$ minute

$250{ }^{\circ} \mathrm{C}$

8 minutes

\subsubsection{Mass Spectrometry Conditions}

Electron energy:

Mass range:

Scan time:
$70 \mathrm{~V}$ (nominal)

30-300 amu

Not to exceed 1 second/scan.

\section{RESULTS}

Initial evaluation of the $\mathrm{K}_{\mathrm{ow}}$ values for the compounds on the COPC list is shown in Table 2.

In "New Concepts in Sorption Based Sample Preparation for Chromatography," Baltussen (2000) notes that the $\mathrm{K}_{\text {ow }}$ value for a compound can be used to predict the $\mathrm{K}_{\mathrm{pdms}}$ value for a compound. In other words, if the $\mathrm{K}_{\mathrm{ow}}$ is low, the $\mathrm{K}_{\mathrm{pdms}}$ is predicted to be low as well. Based on this prediction, compounds with very low $\mathrm{K}_{\mathrm{ow}}$ values like acetonitrile, $\mathrm{N}$-nitrosopyrollidine, N-Nitrosodiethylamine, N-Nitrosomethlyethylamine, and N-Nitrosodimethylamine would not be expected to work. 
Table 2. Chemicals of Potential Concern Compound $\mathrm{K}_{\mathrm{ow}}$ Values

\begin{tabular}{|c|c|c|}
\hline Semivolatile Compound & CAS Number & $\log \mathrm{KoW}^{*}$ \\
\hline Biphenyl & $92-52-4$ & 3.76 \\
\hline Diethylphthalate & $84-66-2$ & 2.65 \\
\hline Dibutylbutylphosphonate & $78-46-6$ & 3.83 \\
\hline Tributylphosphate & $126-73-8$ & 3.82 \\
\hline N-Nitrosodimethylamine & $62-75-9$ & -0.64 \\
\hline 2,6-Di-tetra-butyl-p-cresol & $128-37-0$ & 5.03 \\
\hline \multicolumn{3}{|l|}{ Volatile compounds } \\
\hline Acetonitrile & $75-05-8$ & -0.15 \\
\hline Benzene & $71-43-2$ & 1.99 \\
\hline Butanal & $123-72-8$ & 0.82 \\
\hline 1-Butanol & $71-36-3$ & 0.84 \\
\hline 3-Buten-2-one & $78-94-4$ & 0.41 \\
\hline Butanenitrile & $109-74-0$ & 0.84 \\
\hline 2,4-Dimethylpyridine & $108-47-4$ & 1.90 \\
\hline 2,5-Dihydrofuran & $1708-29-8$ & 0.72 \\
\hline Furan & $110-00-9$ & 1.36 \\
\hline 2-Hexanone & $591-78-6$ & 1.24 \\
\hline Hexanenitrile & $628-73-9$ & 1.82 \\
\hline 2-Methylfuran & $534-22-5$ & 1.91 \\
\hline Pentanenitrile & $110-59-8$ & 1.33 \\
\hline Propionitrile & $107-12-0$ & 0.35 \\
\hline Pyridine & $110-86-1$ & 0.80 \\
\hline N-nitrosodimethylamine & $62-75-9$ & -0.64 \\
\hline N-nitrosom ethylethylamine & $10595-95-6$ & -0.15 \\
\hline Methylene Chloride & $75-09-2$ & 1.34 \\
\hline N-Nitrosodiphenylamine & $86-30-6$ & 3.16 \\
\hline N-Nitrosodi-n-propylamine & $621-64-7$ & 1.33 \\
\hline N-Nitrosodiethylamine & $55-18-5$ & 0.34 \\
\hline N-Nitrosodi-n-butylamine & $924-16-3$ & 2.31 \\
\hline N-Nitrosopyrollidine & $930-55-2$ & 0.23 \\
\hline N-Nitrosopiperidine & $100-75-4$ & 0.72 \\
\hline \multicolumn{3}{|l|}{ SVOA Internal Standards } \\
\hline 1,4-Dichlorobenzene-d4 & $3855-82-1$ & $\mathrm{NA}$ \\
\hline Naphthalene-d8 & $1146-65-2$ & 3.17 \\
\hline Acenaphthalene-d10 & $15067-26-2$ & $\mathrm{NA}$ \\
\hline Phenanthrene-d10 & $1517-22-2$ & NA \\
\hline Chrysene-d12 & $1719-03-5$ & $\mathrm{NA}$ \\
\hline Perlene-d12 & $1520-96-3$ & NA \\
\hline \multicolumn{3}{|l|}{ VOA Internal Standards } \\
\hline Hexafluorobenzene & $392-56-3$ & 3.20 \\
\hline Trifluoromethylbenzene & $98-08-8$ & 2.96 \\
\hline 1-Bromo-4-fluorobenzene & $460-00-4$ & 3.08 \\
\hline Bromobenzene-d5 & $4165-57-5$ & $\mathrm{NA}$ \\
\hline
\end{tabular}

* KowWin Program, Interactive LogKow (KowWin) Demo, Syracuse Research Corporation, Copyright 1999, http://www.syres.com/eSc/est kowdemo.htm

In this work, the chemicals marked in bold in Table 2 were evaluated for analysis using Twisters to extract them from liquids or solids. Some of the other compounds listed on the COPC list were not available as standards. N-nitrosodimethylamine and Nitrosomethylethylamine were tried even though the $\mathrm{K}_{\mathrm{ow}}$ values indicated that they might not work, and as expected, they did 
not work. However, $\mathrm{K}_{\mathrm{ow}}$ values are not a foolproof predictor for how well a compound will work. The 2,6-ditetra-butyl-p-cresol, and furan have high enough $\mathrm{K}_{\mathrm{ow}}$ values that one would expect them to extract with Twister, but the laboratory was unable to get either of them to repeatedly extract from liquid or solid matrices. When examining a homologous series such as acetonitrile through hexanenitrile, it is seen that the $\mathrm{K}_{\mathrm{ow}}$ values increase from acetonitrile, which has a $\mathrm{K}_{\text {ow }}$ of -0.15 , to hexanenitrile, which has a $\mathrm{K}_{\text {ow }}$ of 1.82 . The MDLs for these nitriles get progressively lower as the compounds get larger with higher $\mathrm{K}_{\mathrm{ow}}$ values, indicating increased sensitivity for each compound in the series as the carbon chain gets progressively longer. Acetonitrile is recommended by the manufacturer of the Twister as a solvent of choice for cleaning the Twisters because of the low $\mathrm{K}_{\mathrm{ow}}$ value. Propionitrile could not be extracted from liquids or solids using Twister, but butanenitrile, pentanenitrile, and hexanenitrile were successfully extracted and determined by the method.

Figure 1 is an example of a chromatogram of an LCS for the VOAs.

Figure 2 shows an example of a chromatogram of a LCS standard for SVOAs extracted and analyzed using Twister.

\section{CONCLUSIONS}

Repeatability studies were performed for VOA and SVOA compounds by analyzing replicate extractions of a mid-range standard from a source independent from the calibration standard, (LCS). Results of these studies are shown in Tables 3 and 4. All results are given in percent recovery.

The results of a SVOA LCS determination in diluted tank simulant are shown in Table 5. Terminal Liquor Standard (Terliq), a nearly saturated, extremely basic solution was used as a tank simulant. The Terliq standard is composed of a high concentration of aluminum, sodium nitrate, and sodium nitrite in $50 \%$ sodium hydroxide with lower quantities of sodium chloride, sodium fluoride, sodium sulfate, and sodium phosphate, tribasic decahydrate (LR-332-111, "Terminal Liquor Standards").

The results in the sample, adjusted to $\mathrm{pH} 10$, were within the administrative limits for standard percent recovery of 65 to $135 \%$.

The method was applied to analysis of tank simulants containing oil reported in interoffice memorandum WRPS-0800035, "Report for Hydraulic Fluid Interaction Study." The samples were successfully analyzed for SVOA compounds. Analysis of SVOA standards in pH 10 water and standards spiked into basic solutions of tank simulants can be successfully carried out using Twister stir bar sorptive extraction providing the $\mathrm{pH}$ of the solution is kept to about $\mathrm{pH} 10$ or less. Volatile organic analysis compounds can be analyzed from solids or from $\mathrm{pH} 10$ liquids. 
RPP-RPT-40139, Rev. 0

Figure 1. Volatile Organic Analysis Chromatogram Example

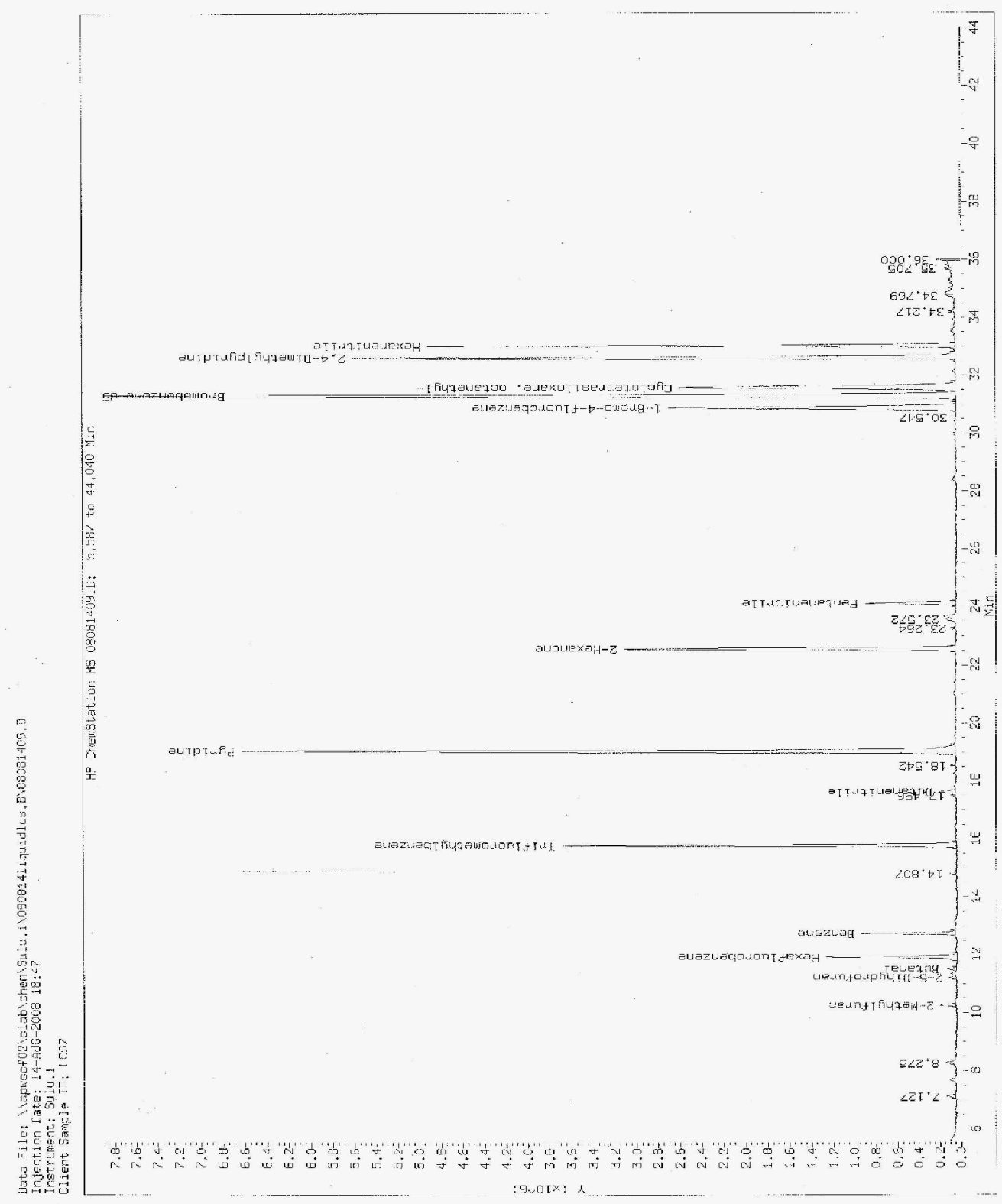


RPP-RPT-40139, Rev. 0

Figure 2. Semivolatile Organic Analysis Chromatogram Example

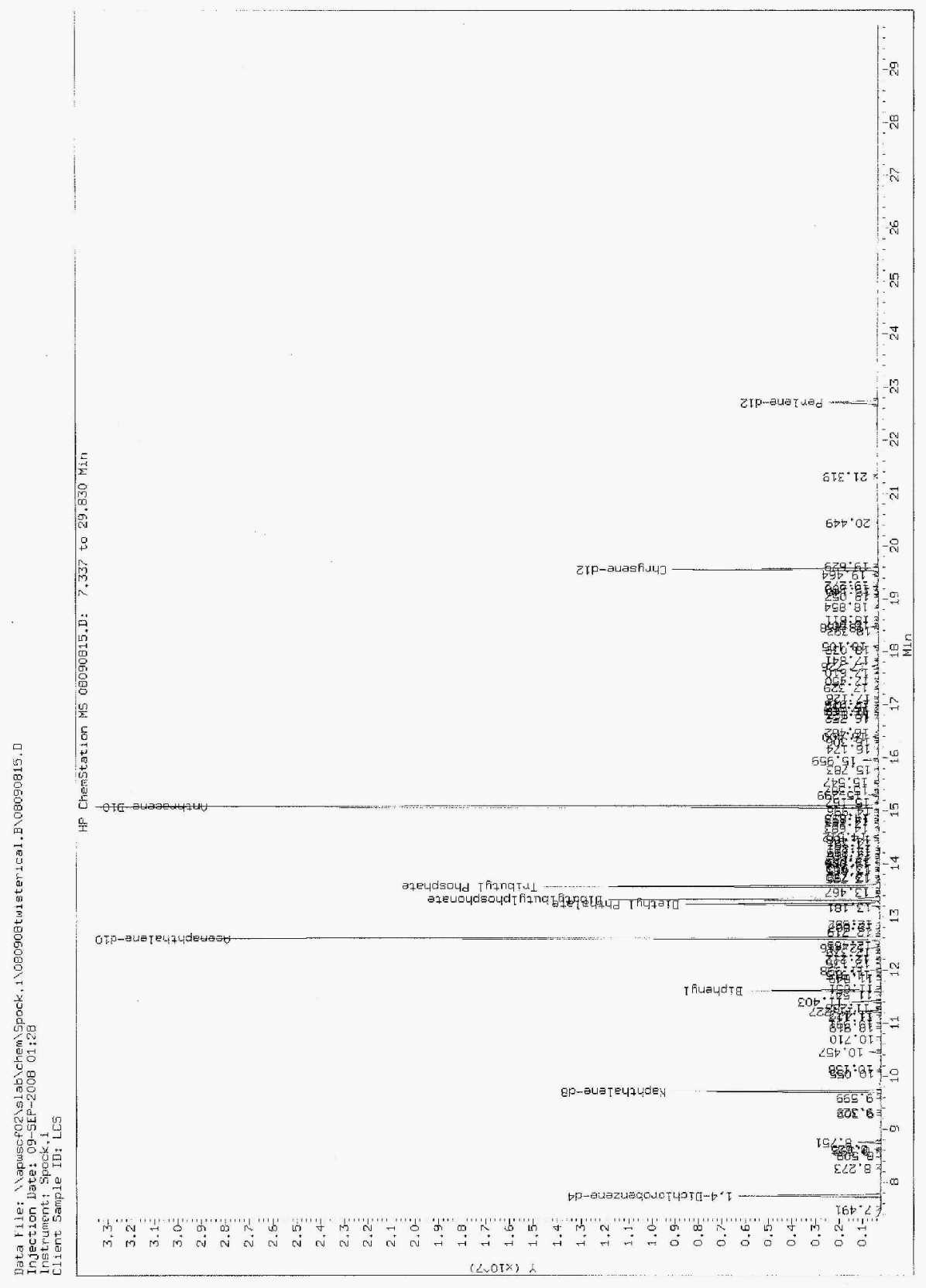


RPP-RPT-40139, Rev. 0

Table 3. Volatile Organic Analysis Repeatability

\begin{tabular}{|l|c|c|c|c|c|}
\hline $\begin{array}{c}\text { Compound from } \\
\text { Solids }\end{array}$ & $\begin{array}{c}\text { Number of } \\
\text { Replicates }\end{array}$ & $\begin{array}{c}\text { Average \% } \\
\text { Recovery }\end{array}$ & $\begin{array}{c}\text { Standard } \\
\text { Deviation }\end{array}$ & $\mathbf{- 1}$ o & $+\mathbf{1}$ \\
\hline 2-Methylfuran & 7 & 104.41 & 27.61 & 76.80 & 132.02 \\
\hline 2,5-Dihydrofuran & 7 & 103.55 & 10.13 & 93.42 & 113.69 \\
\hline Benzene & 7 & 108.23 & 10.57 & 97.67 & 118.80 \\
\hline Pyridine & 7 & 99.25 & 8.19 & 91.07 & 107.44 \\
\hline 2-Hexanone & 7 & 102.65 & 5.99 & 96.65 & 108.64 \\
\hline Pentanenitrile & 7 & 120.51 & 7.10 & 113.41 & 127.61 \\
\hline Hexanenitrile & 7 & 111.36 & 6.09 & 105.27 & 117.45 \\
\hline 1-Butanol & 7 & 111.90 & 16.54 & 95.36 & 128.44 \\
\hline Butanenitrile & 7 & 97.23 & 4.56 & 92.67 & 101.80 \\
\hline 2,4-Dimethylpyridine & 7 & 101.58 & 6.03 & 95.55 & 107.61 \\
\hline Butanal & 7 & 107.21 & 8.02 & 99.19 & 115.23 \\
\hline 3-Buten-2-one & 7 & 115.07 & 13.48 & 101.59 & 128.55 \\
\hline Compounds from & & & & & \\
\hline Liquid & & & & & \\
\hline 2-Methylfuran & 7 & 130.68 & 30.92 & 99.77 & 161.60 \\
\hline 2,5-Dihydrofuran & 7 & 89.54 & 17.92 & 71.61 & 107.46 \\
\hline Benzene & 7 & 120.29 & 9.87 & 110.42 & 130.17 \\
\hline Pyridine & 7 & 100.92 & 17.55 & 83.37 & 118.47 \\
\hline 2-Hexanone & 7 & 98.57 & 16.80 & 81.77 & 115.37 \\
\hline Pentanenitrile & 7 & 111.69 & 12.48 & 99.20 & 124.17 \\
\hline Hexanenitrile & 7 & 105.82 & 10.78 & 95.05 & 116.60 \\
\hline Butanenitrile & 7 & 84.72 & 12.72 & 72.00 & 97.43 \\
\hline 2,4-Dimethylpyridine & 7 & 90.44 & 10.82 & 79.62 & 101.27 \\
\hline Butanal & 7 & 91.54 & 11.70 & 79.84 & 103.24 \\
\hline
\end{tabular}

Table 4. Semivolatile Organic Analysis Repeatability

\begin{tabular}{|l|c|c|c|c|c|}
\hline Compounds from Liquid & $\begin{array}{c}\text { Number of } \\
\text { replicates }\end{array}$ & $\begin{array}{c}\text { Average \% } \\
\text { Recovery }\end{array}$ & $\begin{array}{c}\text { Standard } \\
\text { Deviation }\end{array}$ & $\mathbf{- 1 ~ \sigma}$ & $+\mathbf{1}$ \\
\hline Biphenyl & 21 & 115.55 & 15.80 & 99.75 & 131.36 \\
\hline Diethylphthalate & 21 & 92.03 & 26.75 & 65.28 & 118.78 \\
\hline Dibutylbutylphosphonate & 21 & 98.77 & 35.22 & 63.55 & 133.99 \\
\hline Tributylphosphate & 21 & 100.96 & 27.80 & 73.16 & 128.76 \\
\hline
\end{tabular}

Table 5. Percent Recovery of LCS Standards in Terliq with Twister

\begin{tabular}{|l|c|c|}
\hline Compound & 1mL Terliq + LCS pH>10 & 1mL Terliq + LCS $\mathbf{~ H ~}=\mathbf{1 0}$ \\
\hline Biphenyl & 95.6 & 102.3 \\
\hline Diethyl phthalate & 61.9 & 98.6 \\
\hline Dibutylbutyl phosphonate & 69.0 & 74.8 \\
\hline Tributyl phosphate & 63.9 & 82.5 \\
\hline
\end{tabular}


RPP-RPT-40139, Rev. 0

\section{REFERENCES}

7S110-JMF-07-132, 2007, "Development of Stir Bar Sorptive Extraction as Applied to Hanford Tank Waste Liquids and Solids or Soils" (interoffice memorandum from J. M. Frye to K. M. Hall, dated October 9), CH2M HILL Hanford Group, Inc., Richland, Washington.

Baltussen H. A., "New Concepts in Sorption Based Sample Preparation for Chromatography," E. G. Gerstel, H. Gerstel, R. Bremer, GERSTEL GmbH \& Co, KG, Technische Universiteit Eindhoven, 2000, Proefschrift, ISBN 90-386-2971-0, NUGI 813.

Compendium Method TO-17, 1999, Determination of Volatile Organic Compounds in Ambient Air Using Active Sampling onto Sorbent Tubes, Second Edition, U.S. Environmental Protection Agency, Cincinnati, Ohio.

KowWin Program, Interactive LogKow (KowWin) Demo, Syracuse Research Corporation, Copyright 1999, http://www.syres.com/eSc/est kowdemo.htm

LR-332-111, Rev. I-0, “Terminal Liquor Standards," Advanced Technologies and Laboratories International, Inc., Richland, Washington

WRPS-0800035, 2008, interoffice memorandum, "Report for Hydraulic Fluid Interaction Study" (interoffice memorandum from H. J. Huber to W. G. Barton, dated October 14), Washington River Protection Solutions LLC, Richland, Washington.. 


\section{Electronically Approved by:}

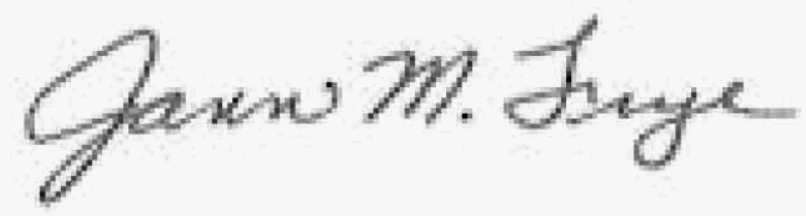

UserName: Frye, Jann (h0049995)

Title: APD Chemist

Date: Tuesday, 03 March 2009, 09:17 AM Pacific Daylight Time

Meaning: Approved by the author or delegate

UserName: Hall, Kathleen (h0068436)

Title: AST Manager

Date: Tuesday, 03 March 2009, 09:42 AM Pacific Daylight Time

Meaning: Approved by the customer or delegate

UserName: Seidel, Cary (h0009079)

Title: APD Manager

Date: Wednesday, 04 March 2009, 09:31 AM Pacific Daylight Time

Meaning: Approved by the APD Manager or delegate 